\title{
FORMATION OF GEOGRAPHICAL LITERACY THROUGH SYSTEMS OF CONCEPTS
}

DOI: https://doi.org/10.18509/GBP210593v

UDC: 37.02:911

\author{
Maya Vasileva \\ Sofia University "St. Kliment Ohridski", Faculty of Geology and Geography, Bulgaria
}

\begin{abstract}
The accelerated course of our country on the way to building a developed democratic society has set many and responsible tasks for the preparation of the young generation. This drew the attention of state policy to the problems of education, to the development and adoption of a number of documents. They outline the educational strategy of the state towards the formation of a complex, competent, promising persona, capable of full realization in life. As the main goal of the high school, it obliges us to look for new approaches in determining the goals, educational content, organization, forms and methods of educational work. The course towards intensification of education must be aimed at achieving the goals in maximum compliance with the immediate and future needs of our democratic development; to decisive improvement of the educational content, by increasing its scientific-theoretical level, practical-applied orientation, educational value; to the organization and methods of training, which allow to develop the activity and initiative of the personality, to use the possibilities of the human intellect. Geography education is also emerging in new aspects. And if until recently it was thought that through this subject students are mainly acquainted with geographical objects, processes and phenomena, at this stage it is necessary to restructure the teaching of geography so that they do not just learn geographical knowledge, but to understand, to master the regularities of the geographical environment in the conditions in which a person lives, works, is formed as a person and which can to some extent purposefully change and manage. Geography education should contribute to the formation of such an image of the young generation, which will be a condition for its social realization.

Closely related to the above problems is the question of the formation of concepts in the geography education. As one of the main issues of modern didactics of geography, its current didactic-methodological characteristics are offered here. Emphasis is placed on the following main points: the place of concepts in the cognitive process; concepts as a logical form of thinking; psychological and pedagogical requirements for the formation of geographical concepts in the learning process; methodological aspects in the formation of concepts in the teaching of geography.
\end{abstract}

Keywords: geography didactics, geography education, geographical literacy, geographical concepts

\section{INTRODUCTION}

What is the place of concepts in the cognitive process?

Human knowledge is not just a passive perception and reflection of the world. It has an active and creative character, which is expressed in the ability of man to know the objective reality and purposefully change it according to social needs. On the other hand, in the process of cognition man himself changes, his cognitive abilities are improved. 
This is the staging that is essential for the implementation of the learning process. What is the result of human cognitive activity? This is knowledge. As a form of assimilation of reality, it is the ability of man in his thoughts, goals, desires, activities to reproduce things, processes, to operate with their images, concepts. Geographical knowledge is also the result of the complex and long process of human knowledge.

A very important aspect of human knowledge that is essential for the learning process in geography is that it is a constant movement, a transition from ignorance to knowledge, from more elementary to more in-depth knowledge. This process has many aspects that are interconnected and have different roles in cognitive activity. One of these aspects concerns the problem of the sensory and the rational in cognition. It is the knowledge from a modern point of view that is an important condition for improving the formation of concepts in the teaching process of geography.

The sensory and the rational in knowledge are interrelated, "the essence of things is known through the knowledge of the phenomenon or the rational knowledge is realized with the help of the sensory, and the sensory in knowledge cannot be realized without thinking and language, ie. without the rational" [4]. This formulation has long given reason for a number of authors to consider the sensory and the rational not as successively alternating degrees of knowledge, but as two moments that "permeate it in all its stages of development." [6], [8], [10]. „The unity of the sensory and the rational in cognition means not following one after the other, but necessarily the participation of both in cognition" [10],[1]. This interpretation confirms that scientific abstractions are a subjective reflection of objective reality, but living contemplation presupposes activity, not ,... a passive reaction of the human sense organs to the influence of the surrounding world, simply „looking“ [5]. The staging is of great importance for understanding the basic requirements for the formation of basic concepts in the teaching process of geography, e.g. those about the role and place of visualization, the activity of students in the learning process, etc.

In the process of cognition, different levels can be distinguished, which as peculiar degrees of knowledge differ from each other in their completeness, depth, versatility of coverage of the object; on the ways of reaching the basic content of knowledge; in the form of its expression. In this case we are talking about empirical and theoretical knowledge, issues of great importance in the formation of concepts. In many cases in the teaching of geography, when through observations of natural and economic-geographical objects, processes and phenomena their description is reached, their external features, connections, states are revealed and their essence, genesis, change and development. Then the students' knowledge remains on an empirical level. This may be the result of educational content that does not correspond to the age characteristics of the students, as well as the result of imperfections in the methodology of teaching geography.

The course of the cognitive process and the formation of concepts are closely related to basic categories, such as concrete and abstract in knowledge. They reflect the changes in the cognitive image, both in terms of the versatility of the scope of objects and the depth of penetration into their essence, reflect the patterns of change in the content of knowledge throughout its development [10], [14]. In the case of the sensory in cognition, the image has a sensory-specific character, the knowledge about geographical objects, processes and phenomena is multifaceted, but covers only their directly perceived external aspects and properties (size, shape, color, distribution, etc.) the concrete is only a starting point of knowledge and in the formation of concepts in the learning process in geography. This is 
expressed in the need for appropriate illustration, from direct observations of the studied objects and phenomena.

Abstract knowledge, in which the essential aspects and properties are separated, is more one-sided, but at the same time - deeper knowledge, because it reveals the essential, the regular, the universal in things. Abstraction simplifies, roughens, schematizes things and reality, so in the process of cognition thought ascends from the abstract to the new concrete - the "concrete in thinking", which appears as a summary and result. It is the ultimate goal of knowledge, the ultimate goal in the formation of concepts [4]. For it, the knowledge of reality is deep and meaningful, because it reflects the various essential aspects, connections, relations of things, because it reveals the connections of the singular with the universal and gives grounds to be considered as "unity of diversity". The concrete in thinking in the formation of concepts should lead students to a true knowledge of geographical objects, processes and phenomena, which should include the unity of the essence and its diversity. Eg. the formation of the concept of climate begins with the specific knowledge of the climate of the native place and passes through abstractions and generalizations in order to arrive at the disclosure of the content and formulation of the definition of the general concept. On this basis, we ascend to the new concrete in thinking as a unity of general knowledge about the nature of climate and its diversity around the globe, continents, countries and regions, depending on the peculiar manifestation of climatic factors.

The formation of concepts in the teaching process of geography is also related to understanding the unity of the historical and logical method in knowledge. The historical presupposes the study of the origin and development of natural-geographical and economic-geographical objects, processes and phenomena, which explains many of their modern peculiarities. However, this can be done in close connection with the logical method, which reproduces in theoretical form the content of the historical process in a system of judgments, concepts and inferences.

The concept - a logical form of thinking

Logical thinking is generalized and mediated knowledge, it is abstract thinking, ie. thinking with concepts. "The concept is a reflection of the general, and essential features of the class of objects" [2]. The class, in turn, is a set of individuals who have common features (properties, relationships). "An individual is understood as an object, a phenomenon, an animal, a person ..., in a word, everything that has an independent existence (ibid., 90). Classes are not created by people, they exist objectively, and people form concepts about them. Eg. The Danube is an individual that can belong to the less general class of "rivers in Europe", but can also belong to a wider class - "rivers".

The most characteristic feature of the concepts is that they reflect the essence of things, and these are the internal objective connections, which as a "genetic basis" define all other particular features of the whole. Eg. the nature of the climatic zone is determined by the internal causal relationship between its location at a certain latitude and the resulting approximately uniform climate. This connection is common to all climatic zones and determines their features. The essence of many things can be revealed by examining the process of their origin (genesis) and development. "To have a concept of an object means to have a common way of constructing it, to have knowledge of its origin ..., to know the ways of working with it, which have caused the need for its emergence in people's work" [6]. These formulations point to certain requirements both in terms of curricula and textbooks, and in terms of teaching methodology in the formation of concepts. 
The peculiarity of the concept as a logical form of thinking is that it gives knowledge of the general. The common is a country, an essence, a moment of the singular, ie. it is given in the singular. On the other hand, we know the singular through the common, because the singular consists of common sides, moments, its essence is common [3], [17]. This statement is of great importance for the methodology of concept formation. Thus e.g. the single term "island of Greenland" on the one hand contains the common feature of all islands [18], and on the other hand - on the basis of universal knowledge for all islands can reveal the specific, special in formation, area, surface, climate and etc. on this island, which makes it unique.

The concepts should be considered in their amendment and development. An objective source for this is, on the one hand, the development of our knowledge of objective reality, which determines a deeper knowledge of the essence of things, its concretization, and on the other - the change of reality itself, which the concepts reflect. In the second case, new concepts emerge, which enriches human knowledge, science. Therefore, we can talk about the flexibility of concepts, about their transition from one to another (e.g. thermal zone - climate zone - natural geographical zone). At the same time, the flexibility of concepts must be combined with their relative stability, certainty, which allows the distinction of concepts and the disclosure of their peculiar nature. As a result of the continuous development of geography as a science, changes occur in its conceptual apparatus. These changes are reflected both in the new, more modern formulations of some concepts (subject of geography) and in the formation of relatively new branches of science and the related emergence of new systems of concepts.

In summary, the problem of change and development of concepts is reflected in the teaching of geography in the following aspects:

- 1. he knowledge about the essence of some geographical objects, processes and phenomena, about the content of their concepts according to the age peculiarities of the students is deepened and changed, which finds expression in the spiral arrangement of the material studied in the curriculum and the way of revealing this content in textbooks (e.g. the concept of "time" is studied at different levels in fifth and eighth grade).

- 2. The knowledge about the diverse manifestation of the essence of a given concept is enriched, its volume is increased by studying many single objects, where the knowledge rises to a new quality (eg the students' knowledge about the diverse manifestation of the climate in different continents, countries is enriched and areas throughout the training course).

- 3. Qualitative changes in the system of geographical concepts are also the result of quantitative changes in it with the inclusion of new concepts to be studied (eg "relief profile" in the sixth grade).

As is well known, there are relationships and interrelations between things and phenomena in reality, and the concepts reflect this reality. Therefore, there are also relations and connections between the concepts. The relationship between concepts as a reflection of the relationship between things determines the formation of systems of concepts in scientific knowledge in general and in particular - in individual sciences. This facilitates the process of cognition and at the same time allows for its further development. The relationship between geographical concepts is a reflection of the relationship between the three main agents: man (society) - production - nature (natural environment). The construction and study of systems of concepts in the teaching of geography have important methodological significance. In this way a logical and psychological basis for 
the successful course of the cognitive activity in the learning process, in the individual lesson, a greater depth, scientificity and systematization of knowledge is achieved, a worldview is formed. This is a basic position in our methodology [4], aimed at forming the geographical culture of students [3], [17], [21].

Of particular importance for the formation of concepts in the teaching process of geography are studies of the content and scope of concepts. The problem is as follows:

- 1. In some cases the content of the concept is scientifically revealed and does not change further in the course of study, but the volume of the concept changes. This is the case with the term 'map'.

- 2. The way of revealing the content of the concept is changed from more elementary to more profound, scientific, e.g. in the concept of "natural geographic zone" in seventh and tenth grade.

What are the psychological and pedagogical requirements for the formation of geographical concepts in the learning process?

The formation of geographical concepts is a long and complex process. It begins from an early age with the formation of the so-called life concepts that are formed as a result of the daily life experience of children. In life concepts, knowledge is limited, elementary in content. Scientists use words, terms, with which they fix the concepts, but in fact the generalizations created by them remain at the level of empirical knowledge. Thus e.g. in the process of their life experience children learn a certain range of geographical terms. They talk about mountains, the weather during the day and more, having regard to many of the insignificant features of these concepts („mountains“ are high parts of the earth where there are forests, rivers“; ,weather is whether it is hot or cold"). True knowledge of the nature of objects, processes and phenomena of the real world is obtained through scientific concepts that reveal the inner essential and common features of things [4].

Interesting for the teaching process in geography is the relationship between life and scientific concepts. In the pedagogical literature this problem is still not sufficiently developed. It is generally accepted, however, that in many cases the development of life concepts prepares the mastery of the system of scientific concepts, and in other cases empirical knowledge prevents students from rising to the level of theoretical thinking [7]. This also applies to teaching geography [19], [20].

The formation of geographical concepts finds its most purposeful and harmonious manifestation in high school, where it is a purposeful cognitive process, which is carried out through the joint activities of teacher and students.

The successful formation of the concepts largely depends on what the student perceives, and this depends on three factors:

- 1. From the object itself (what aspects in it are more pronounced)

- 2. From the personal experience of the students (which features are most familiar)

- 3. From the teaching methodology (what features the teacher emphasizes, or the students take notes of) [15].

For a long time, many authors have emphasized the need for a special selection of objects for observation, which must reveal both the essential common in things and the diverse manifestation of the common. This gave grounds to widely recommend the perception of a large number of objects, of "rich factual material" [13], [16]. The current statement in contemporary literature is that the observation and comparison of many objects is not necessary to illustrate a feature as essential. It is only necessary for the sign to be significant for them and then they will separate it even from one object, subject [6], [15], [20]. 
The personal experience of the students, expressed in perceptions, ideas, concepts, activity, plays a big role in the formation of the concepts. The important thing here is to emphasize, however, that the old knowledge must be used from a new point of view, for a new classification of objects, for a new solution of problems. "Life experience should be used in education, but only in the way of its essential reorganization into a qualitatively new form of scientific knowledge for the student, which does not correspond and cannot correspond to the simple life experience" [6]. In this sense, ideas and desires play the role of "handy material" in the formation of the new concept.

The formation of concepts in the learning process presupposes a deep mental activity, which is based on the logical operations of analysis, synthesis, comparison, classification and especially abstraction and generalization.

What are the methodological aspects of the formation of concepts in teaching geography?

The study of the methodological literature shows that the elaborations on the problem of the concepts are directed in three directions - the system and the content of the concepts in the teaching of geography, the classification and the formation of the geographical concepts [3], [17], [19], [20].

The scientific level of education finds the most concrete expression in the coherent and interconnected system of general concepts. In this sense, the basics of geographical sciences should be introduced in school through generalization of scientific material, increasing scientificity by strengthening the part of basic knowledge (including concepts) while reducing the more mobile shell (factual knowledge), strengthening typological approaches [12].

In general, all authors are unanimous in the opinion that the concepts along with the laws are a major structural component of geographical knowledge, that teaching geography should be based on systems of concepts, the main features of which are defined unambiguously and scientifically depending on opportunities for students [9], [11], [12], [3], [17].

Based on the studied literature and research on the problem of concepts, the following conclusions can be made:

1. At the heart of the curriculum in geography are systems of concepts and related patterns. They reveal the foundations of science and have a kind of content-logical structures, characterized by the following:

- Each system of geographical concepts consists of separate concepts or subsystems of concepts at different levels.

There are structural and horizontal connections and relations between the concepts and the subsystems, which determine the content-logical structure of the system, its integrity. There are horizontal connections between concepts and subsystems with the same degree of generality, from one level (e.g. industry - agriculture - transport), and vertical (subordination) connections - between concepts with different degree of generalization, at different level (e.g. industry - heavy (group A), light and food (group B). Horizontal links between geographical concepts or subsystems of concepts can be one-way (climate factors - climate elements), two-way (internal earth forces - external earth forces), multidirectional (eg between the components of the geographical envelope. to be expressed in: genetic unity (furrow - ravine - river valley), cause - consequence (atmospheric pressure - wind), partial coincidence (natural area - natural geographical zone), contradiction (market - command-administrative economy). Vertical connections and relationships express subordination and subordination. The subordinate concept is a 
part, a side of the main one (national economy - branch structure), and the subordinates express species differences (branches of the economy - industry, agriculture, etc.).

- The systems of geographical concepts are at different levels - interdisciplinary, intrasubject, within a separate course, title, topic, lesson, paragraph. Each of them is strictly determined by laws, laws and principles of epistemology, logic, psychology, didactics, science, geography, methodology.

- Higher level systems have more complex content-logical structures. Each system of a lower level is a concretization of the higher one.

- The general subject system of concepts in the learning process changes, develops in a spiral. This is reflected in all lower level systems, in the individual concepts.

2. Classification of geographical concepts can be done from two aspects: system-logical (depending on the concepts can be general and single) and system-content (according to the peculiarities of science, geographical concepts can be grouped into subsystems cartographic, natural-geographical, economically).

3. The formation of geographical concepts is a long and complex process, closely related to the system-structural features of the educational content and the application of the respective methodology. Basically, this process in the formation of general concepts includes the following activities: understanding and mastering the content of concepts and related ideas; formation of skills for application of the concepts in a known and in an unknown situation; building and making sense of systems of concepts (Fig. 1).

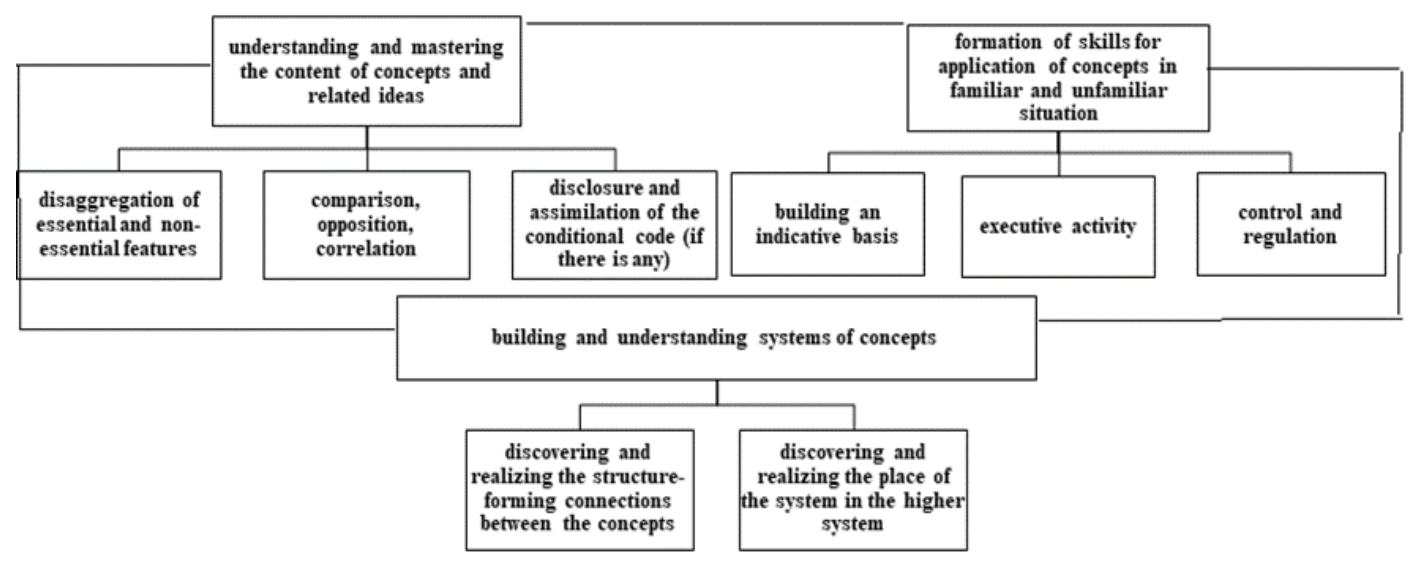

Figure 1. Formation of concepts in teaching geography [4]

The division of these three activities is conditional, as they are very closely interrelated and mutually conditioned. Understanding the content of concepts in some cases is done by performing one or another subject-practical activity, by revealing the place of concepts in a given system. The better the content of the concepts is understood, the faster the skills to operate with them are mastered, the better their place in relevant systems is understood. The understanding and application of some collective concepts presupposes the construction of systems of concepts and the related skills, etc. At the same time, these activities are very complex and have relative independence in the learning process, which requires their differentiation and more detailed consideration.

1. Conditions for successful implementation of activity - understanding and mastering the content of geographical concepts and relevant ideas are: knowledge and use of basic knowledge and skills of students, use of the map, intra-subject and inter-subject relations, 
appropriate illustration, comparison, repetition of essential signs, exercises for recognizing them, etc.

2. Conditions for successful formation of the skills for application of the concepts are: to know with what skills the application of a given concept is connected; the formation of skills to be closely related to the content of the concepts and on the basis of basic skills; to provide all prerequisites for the management of the learning process - clear goals, indicative basis, practice of actions in different situations in control and regulation.

3. Conditions for successful construction and comprehension of systems of concepts are: complete, correct and permanently formed individual concepts, use of the graphic method (schemes, tables), wide activity for revealing various connections, relations, comparison, summarizing activity, etc.

\section{CONCLUSION}

From what has been said so far, it is clear that the problem of forming concepts in the teaching process of geography has a broad theoretical basis. This is a favorable prerequisite for its development in a practical-applied plan, for improving the practice of teaching geography in the spirit of modern requirements.

Given the fact that Bulgaria is part of the European educational area, it is completely reasonable to study the issue on a comparative basis with geographical education in European countries. This presupposes, firstly, the study of specific methodologies applied in these countries and which have proven their effectiveness, and secondly, the derivation of specific possibilities for their adaptation in the practice of teaching geography in Bulgaria.

\section{REFERENCES}

[1] Андреев, М. Процесьт на обучението. С. УИ „Св. Климент Охридски“, 1996

[2] Бънков, А. Логика. С. Наука и изкуство, 1975

[3] Гайтанджиева, Р. Стратегия на географското образование в СОУ при новите реалности, С. Анубис, 2000

[4] Гайтанжиева, Р. Формиране на понятията при обучението по география, С. Народна просвета, 1983

[5] Георгиева, Ф. И. Гносеологические проблемы диалектического материализма. М. Высшая школа, 1981

[6] Давыдов, В. Выды обобщения в обучении, М. Педагогика, 1972

[7] Денев, Д. Формиране на понятията в учебния процес, С. Народна просвета, 1977

[8] Диалектика, логика, теория познания. Сборник. Тбилиси, Мециереба, 1979

[9] Дорн, В. и В. Ян. Формирование представлений и понятий при обучении географии, М. Педагогика, 1970

[10] Копнин, П. В. Диалектика, логика, наука. С. 1971

[11] Коринская, В. А. Формирование понятий при изучении курса географии материков. М. Педагогика, 1979

[12] Максаковский, В. П. Внасяне основите на географската наука в училище - Обучението по география, 1979, № 5

[13] Педагогическа психология. Колектив. С. Народна просвета, 1979

[14] Петров, П. Дидактика. С. УИ „Св. Климент Охридски“, 1992 
[15] Петровски, А. В. Обща психология. С. Народна просвета, 1976

[16] Пирьов, Г. Д. Педагогическа психология. С. Наука и изкуство, 1975

[17] Цанкова, Л. Ръководство по дидактика на географията. С. УИ „Св. Климент Охридски“, 2005

[18] Щукин, И. С. Четырехязычный энциклопедический словарь терминов по физической географии. М. Советская энциклопедия, 1980

[19] Reinfried, S. \& Haubrich, H. (Hrsg.). Geographie unterrichten lernen. Die Didaktik der Geographie. 1. Aufl. Berlin: Cornelsen. 2015

[20] Rinschede, G. Geographiedidaktik. 3. Aufl. Paderborn u.a.: Ferdinand Schöningh 2007

[21] Wasileva, M. Naydenov, K. Atanasov, D. Contemporary Trends in Geographical Education. In: Proceedings of the International conference "InterCarto/InterGIS". 2017.3 (23): pp. 205-210. 2017 